\title{
A normose informacional
}

\section{Pierre Weil}

Doutor em psicologia pela Universidade de Paris. Professor emérito do Departamento de Psicologia da Universidade Federal de Minas Gerais. Presidente da Fundação Cidade da Paz e Reitor da Universidade Holística de Brasília (Unipaz).

\section{Resumo}

Embora reconhecendo a grande contribuição que a informática está dando para a humanidade, o autor atrai a atenção do público sobre aspectos patogênicos e letais de certas aplicações junto de diversas tecnologias. O autor demonstra que existe o que ele chama de normose informacional, que se apresenta sob duas formas: a informatose e a cibernose. Depois de ter definido os critérios de diagnóstico de uma normose, ele demonstra com vários exemplos concretos estes aspectos patogênicos e letais da informática, e sugere o que ele chama de normoterapia.

\section{Palavras-chave}

Normose informacional; Informatose; Cibernose; Neurose virtual; Normoterapia; Informática educacional.

\section{Information normosis}

\begin{abstract}
Although recognizing the great contribution computer science has been giving to the humanity, the author calls the public'c attention to pathological and lethat aspects of some applications by several technologies. The author argues that there is something that he calls informational normosis which shows up under two forms: informatosis and cibernosis. After having defined the criteria of diagnosis of a normesis he demonstrates with several concrete examples these pathological and lethal aspects of computer science and suggests what he calls normotherapy.
\end{abstract}

\section{Keywords}

Informational normosis; Informatosis; Cybernosis; Virtual neurosis; Normotherapy; Educational informatics.

\section{INTRODUÇÃO}

Algumas considerações sobre aspectos patogênicos da nova cultura informacional

Neste início do terceiro milênio, estamos sem dúvida entrando em uma nova fase cultural em que impera a revolução informática, a qual está caracterizando uma nova cultura, a cultura informática ${ }^{1}$. Paradoxalmente, estou me servindo de um computador, efetuando um lindo tratamento de texto, para mostrar os inúmeros aspectos destrutivos da informação.

Por isto mesmo, faço questão de declarar, logo de início, que este trabalho de jeito nenhum invalida o caráter excepcionalmente benéfico que a informação e mais especialmente a informática, incluída nesta, presta à Humanidade.

O sucesso da informática assume um caráter global e tem influências no sentido de beneficiar bilhões de cidadãos deste mundo. Só podemos nos alegrar com a rapidez e universalização da informação via Internet, que está se transformando em uma verdadeira Universidade, onde o médico encontra dados precisos para dirimir dúvidas a respeito de uma doença e onde qualquer estudante de qualquer nível pode juntar dados preciosos para os seus estudos. Em outras palavras, todos os setores de atividade humana estão sendo beneficiados pelas diferentes formas de informática.

Embora o entusiasmo reinante seja bastante generalizado, certos aspectos destrutivos estão aparecendo, ainda encobertos por esta euforia coletiva.

É objetivo do presente trabalho colocar em evidência certos aspetos patogênicos da cultura informacional, que chamaremos de "Normose Informacional".

Antes de entrar no mérito da questão, queremos deixar bem claro que esta explanação tem apenas o caráter de uma nota prévia; é a expressão de algumas reflexões mais ou menos profundas do autor; este artigo não passa de uma mera especulação, que, para o domínio da ciência, pode constituir um manancial de hipóteses a serem confirmadas pelas metodologias convenientes.

Feitas estas prudentes ressalvas, vamos começar por justificar o título de normose informacional. 


\section{O QUE É UMA NORMOSE?}

Normose é um termo que foi forjado por Jean Yves Leloup ${ }^{2}$ na França, e por Roberto Crema ${ }^{3}$, no Brasil. Juntamente com o primeiro, ou separadamente, publicamos uma série de artigos, visando a definir o termo normose ${ }^{4,5,6}$

Eis um resumo sucinto destes ensaios. Normose é o resultado de um conjunto de crenças, opiniões, atitudes e comportamentos considerados normais, logo em torno dos quais existe um consenso de normalidade, mas que apresentam conseqüências patológicas e/ou letais. Alguns exemplos de normoses: usos alimentares como o açúcar, o uso de agrotóxicos e inseticidas, o consumo de drogas como o cigarro ou o álcool, o paradigma newtoniano cartesiano e a fantasia dualista sujeito-objeto em ciência, o consumismo associado à destruição da vida no planeta.

Para demonstrar que a cultura informacional é normótica no seu todo ou em parte, precisamos demonstrar que:

- há consenso quanto à normalidade do uso da informática na cultura;

- há conseqüências patogênicas e ou letais deste uso.

\section{ASPECTOS NORMÓTICOS DA CULTURA} INFORMACIONAL

Trabalhos recentes sobre a existência da informação como fenômeno cultural ${ }^{1}$ por si só nos parecem configurar a existência de um consenso em torno da normalidade do uso da informática. Só o uso da Internet, tomado como exemplo, acusa uma curva assintótica de crescimento atingindo uma dezena de milhões de internautas?

No que se refere aos aspectos patogênicos, podemos classificar estes em duas categorias, a informatose e a cibernose.

A informatose é um termo que criamos para designar distúrbios ou mesmo doenças causados por excesso de fluxo de mensagens informacionais em relação a um só receptor, isto é, a uma só pessoa.

Quanto ao termo "cibernose", ele foi criado por um psicosociólogo francês, Van Bockstaele, para designar nós de estrangulamento nas comunicações, mais especialmente durante uma situação experimental que ele chamava de socioanálise, um método de dinâmica de grupo $^{8}$. Retomamos o termo para designar mais especialmente situações de perturbação de comunicações, com efeitos patogênicos sobre o sistema nervoso, ou funções mentais, causados na sua maioria pelo uso de aparelhos cibernéticos.

Vamos iniciar, pois, com a informatose.

\section{A INFORMATOSE}

Vamos descrever a seguir alguns exemplos de conseqüências patológicas do acúmulo de informações ou simplesmente do uso da informática em certas condições.

\section{Isolamento e desmembramento familiar}

Papai está na internet, o filho está no video game, e mamãe, assistindo à novela das 20 horas na TV. Ninguém mais se comunica ou troca afeto e carinho. Reina um ambiente de frieza completa. Cada um comeu rapidamente na cozinha, ávido para retornar à sua atividade preferida: a informática. Estamos longe do calor dos encontros na mesa ou em torno da lareira. Em vez disto, frieza e indiferença. E, quando membros da família se encontram entre duas portas, parecem fantasmas que se cruzam absortos nos seus pensamentos; nem se cumprimentam.

Uma cena como esta se repete em milhões de lares expressando uma espécie de hipnose coletiva. Até que ponto a informática não estaria contribuindo para agravar ainda mais a desagregação da família, típica da nossa época?

\section{Dissonância cognitiva entre aspiração e capacidade real de absorção da informação}

A discrepância entre o nosso nível de aspiração de, por exemplo, realizar determinada tarefa e nossa verdadeira capacidade de realizá-la a contento é chamada em psicologia de dissonância cognitiva. Esta dissonância cria tensões que, se a dissonância se repetir constantemente, podem levar ao estresse e suas conseqüências psicossomáticas. Parece-nos ser o caso de muitos internautas e também dos titulares de e-mail.

No caso dos internautas, muitos se encontram constantemente na situação de se depararem com milhares de indicações, referências e informações diversas a respeito de cada assunto que estão pesquisando. Eles ficam com a constante ilusão de que podem tudo conhecer. Ficam então noites a fio pesquisando, em um ambiente bem parecido a de jogadores de cassino que nunca perdem a esperança de ganhar e que praticamente nunca ganham. Esta fome de saber já existia no tempo de Simone de Beauvoir a respeito dos livros. No fim da vida, ela chegou à conclusão de que não podemos tudo saber... $\mathrm{O}$ problema é que os internautas arriscam esgotar as suas reservas 
energéticas em apostas infernais. Por trás deste comportamento estão emoções destrutivas, mais particularmente o apego.

O mesmo se dá com o e-mail. Quem tem e-mail está fadado, mais cedo ou mais tarde, a perder a sua liberdade. Existe uma expectativa cada vez mais premente de que você tem a obrigação de responder na hora. Todo adiamento fica preocupante para quem espera, ou mesmo suspeito. Este tipo de pressão aumenta proporcionalmente ao número diário de e-mails. Conheço pessoas que recebem centenas de missivas por dia. Só lhes resta fazer uma seleção superficial e só responder ao indispensável. No fundo, muitos são os que se sentem mal e culpados. E de fato o sentimento tem fundamento, pois todo e-mail não respondido arrisca criar decepção e quem sabe hostilidade do emissor em relação ao receptor da mensagem. Nem todo mundo pode pagar uma secretária...! O problema aumenta ainda mais para as mulheres que trabalham fora e cuidam da casa e dos filhos. O e-mail lhes tira noites de sono, e muitas acabam esgotadas e estressadas.

A realidade é que todos nós fomos tomados de surpresa por este "choque ao futuro", e ninguém nos preparou para evitar estes excessos. Creio que, à medida da tomada de consciência dos perigos do uso excessivo da informática, as pessoas mais avisadas terão de se organizar para preservar a sua saúde mental e física.

\section{A ligação sutil computador-ser humano}

Teilhard de Chardin, no seu livro sobre o lugar do homem na natureza ${ }^{9}$, achou que a máquina é um prolongamento da evolução do ser humano e da sua ação intelectual. Podemos afirmar isto muito mais ainda a respeito do computador. Servan Schreiber, no seu livro O Desafio Mundial $^{10}$, foi ainda mais longe quando afirmou que, no ato de ligar um computador, a inteligência do ser humano entra em contato com a inteligência do eléctron.

Sendo isto uma verdade, podemos nos perguntar se o fato de manipular um computador horas a fio e dia após dia não afetaria, de certo modo ainda desconhecido, o sistema nervoso. Podemos também indagar se esta influência seria benéfica ou não. A pergunta tem cabimento, pois recentes pesquisas de neuropsicologia têm colocado em evidência a existência de estruturas e circulação do influxo nervoso diferentes do analfabeto e do ser alfabetizado.

Pessoalmente, todas as noites em que trabalhei com o computador, a minha mente, eu já me encontrando deitado na cama, funciona de modo diferente; algo se passa como se o teclado fizesse parte do meu sistema nervoso e houvesse uma interdependência tal que começo a pensar em termos cibernéticos. Tudo se passa como se eu estivesse pensando com o teclado, ou algo semelhante que tenho muita dificuldade em definir para mim mesmo e ainda mais expressar para o leitor destas confabulações. A palavra deletar, por exemplo, já entrou no meu vocabulário para significar o ato de suprimir um pensamento ou partes desagradáveis de uma lembrança minha! Eu não ficaria surpreso, se leitores se reconhecessem nesta minha descrição. Creio que há algo muito importante a pesquisar de modo interdisciplinar. A palavra que me vem à mente neste momento é "simbiose neurocibernética". Esta pesquisa poderia verificar esta hipótese de simbiose entre o hardware e o software de um lado, e o sistema nervoso do usuário de outro lado.

\section{A neurose do virtual}

Assisti recentemente a uma entrevista na TV de uma psicoterapeuta brasileira que se especializou no tratamento de internautas que perderam contato com a realidade do cotidiano ou que apresentam dificuldades neste sentido. A terapeuta observou que o fato de passar horas lidando com programações virtuais muda por completo a visão do mundo, onde tudo também se tornaria virtual para o paciente. Não tive a presença de espírito de tomar nota do nome desta terapeuta. Mas o assunto que ela apresenta se inscreve muito bem como informatose dentro da normose informática e merece uma pesquisa aprofundada.

\section{A questão da divulgação da violência}

Tudo indica que a divulgação de informações sobre atos violentos pelos noticiários como jornais, rádio e TV contribui para o aumento da violência. Os profissionais das mídias sabem disto, e tenho notícias de que isto preocupa muitos deles. É uma informatose, pois produz ferimentos, sofrimentos e morte, e faz parte considerar como normal a divulgação de qualquer informação. Quantos psicopatas e psicóticos, ao assistir a detalhes horríveis de cenas violentas, não estão tentados compulsivamente a fazer o mesmo? Ao mesmo tempo, os próprios assaltantes recebem diariamente verdadeiras aulas áudio-visuais, instruindo-os a agir cada vez de modo mais refinado e eficaz. Não sabemos até onde a autocensura que já existe no caso de suicídios de adolescentes não deveria se estender às notícias violentas em geral. Dar detalhes horripilantes e divulgá-los com bastante ênfase não será um ato de sadismo inconsciente de jornalistas ou de necessidade de sensacionalismo, de vender jornal ou de ter Ibope para vender anúncios? Será que estas notícias têm alguma utilidade em si? 
O mesmo podemos dizer dos programas e filmes violentos na TV ou no cinema. Recentes resenhas de pesquisas feitas pela Unesco ${ }^{11}$ não deixam pairar dúvidas a respeito da influência da TV sobre o comportamento violento de jovens. Ainda recentemente em Brasília, depois de ter assistido ao seriado Bonecas assassinas, um menino de oito anos colocou a sua irmã menor na banheira e a espetou umas vinte vezes. Interrogado, afirmou que ele não conseguiu se conter para evitar este ato bárbaro. Um bom aluno da TV, não é?

Ainda hoje, na hora de terminar este artigo, vejo uma notícia no jornal, informando que a Mac Farlane Toys acaba de lançar um novo boneco intitulado Death Row Mary, isto é, Mary Corredor da Morte. Trata-se de um boneco, exemplo de robô inteiramente informatizado, sentado na cadeira elétrica. Ao condenar o boneco à morte, a criança liga a corrente elétrica; então, os olhos do boneco ficam vermelhos, o seu corpo inteiro passa a tremer; então ele lança um grito : "É o melhor que vocês podem fazer, seus...?". Que maravilha! E o melhor é que a fábrica tem a ingenuidade de limitar a venda para a idade de 13 anos acima, como se meninos e meninas de 13 anos não fossem influenciáveis por esta violência de brincar de carrasco...! É claro que o título do artigo contribui para venda do jornal; veja só: "Boneco morre na cadeira elétrica" ${ }^{\text {"2 }}$. Ainda bem que o redator da notícia ressaltou o reboliço e a onda de protestos deflagrada pela notícia, entre outros o da Associação Americana de Pais de Crianças Assassinadas.

E neste sentido de disseminação da mentalidade violenta podemos assinalar aqui a atuação dos video games na alma das crianças e dos adolescentes. Grande parte destes jogos consistem em atirar e matar os heróis e personagens dos programas. Que ação tem isto na alma do jovem? Ainda sabemos muito pouco a respeito. Mas é mais do que justificada a preocupação de inúmeros educadores a respeito do fato de que há muitos jovens que ficam horas a fio nos video games, o que constitui um verdadeiro treino ou condicionamento para achar natural o ato de matar. Até que ponto não haveria um fenômeno de banalização do ato de matar? A pergunta vale aliás para toda a divulgação da violência nas diferentes modalidades que acabamos de descrever, tanto para os filmes, como as notícias violentas na TV.

E agora vamos descrever os principais aspectos da segunda categoria de manifestações patogênicas que agrupamos sob o título de "cibernose".

\section{A CIBERNOSE}

Vamos, em primeiro lugar, nos ocupar de efeitos de atrofias de funções humanas devidas ao uso do computador, ou de calculadoras, para depois tratar de distúrbios nas comunicações e relações humanas, causadas pelo uso indevido do celular, da secretária eletrônica e da música de espera.

\section{Desequilíbrio dos hemisférios cerebrais}

Já é fato notório que a nossa educação se tornou apenas uma instrução intelectual, consistindo em armazenar quantidade enorme de informações, ou treinando o raciocínio lógico matemático. Todas estas funções estão ligadas ao hemisfério esquerdo do cérebro. A criatividade, ligada ao hemisfério direito, é pouco estimulada pela informática. Na educação, as crianças e adolescentes vêem atrofiadas as funções ligadas ao hemisfério direito e se tornam dependentes do computador.

Consciente disto, uma equipe do Ministério da Educação criou uma nova metodologia, a Informática Educacional ${ }^{12}$, em que o aprendiz coloca no computador o produto da sua criatividade. É uma maneira de corrigir o desequilíbrio em questão.

O problema causado por esta atrofia da criatividade e da intuição ultrapassa muito o aspecto educacional da questão. Por trás desta questão, encontra-se a distorção de toda nossa cultura, dominada há milênios por uma normose machista, que reprimiu o lado direito do cérebro, isto é, as funções femininas de abertura, beleza e amor, o que é apenas uma expressão do confinamento da mulher no lar e da repressão do lado feminino na maioria dos homens. O próprio movimento feminista teve de imitar a normose machista para vencer esta batalha pela igualdade entre os sexos. $\mathrm{O}$ resgate do feminino ${ }^{13}$, reivindicado recentemente pelas remanescentes líderes feministas, é uma necessidade urgente, tanto na mulher masculinizada quanto no homem machisado, o qual gerou esta cultura tecnológica sobre a qual iremos falar mais adiante. Por trás da adaptação do computador ao lado direito do cérebro, o lado feminino, está um ideal muito mais abrangente: o fim da guerra dos sexos e o advento de uma nova civilização de paz, amor e plenitude.

\section{Atrofia da função numérica da mente humana}

Era uma vez um rapaz que sabia usar o cálculo mental sem necessidade de nenhuma máquina. O Conselho Nacional da Pesquisa Científica do Governo Mundial resolveu investigar este caso, raríssimo entre os seres humanos deste planeta Terra. Só se tem notícia de dois casos, um do ano 
5043, e o outro, mais recente, do ano 5503, isto é, há cento e dez anos aproximadamente. As conclusões da investigação confirmam as dos dois casos anteriores. Tratase de uma função que teria pertencido a uma civilização passada, da qual não se tem muito conhecimento, pois foi arrasada por uma virada do eixo da Terra.

Era uma época selvagem em que inexistiam as nossa maravilhosas energotecnologias que substituem com muita vantagem esta função atrofiada. Parece que o rapaz está dando treinamento para os que querem adquirir este dom misterioso e fascinante.

O leitor adivinhou, nesta altura, que se trata de uma história que inventei para nos introduzir ao assunto e que se passa em um futuro longínquo de mais de 5 mil anos à frente.

Esta história tem cabimento, pois estou, como psicólogo treinado na observação humana, alarmado com evidências que saltam aos meus olhos e que qualquer um, uma vez avisado, pode observar.

Em primeiro lugar, observei que, nas lojas, a nova geração de vendedores não consegue mais fazer uma simples operação aritmética, levando um tempo enorme se a máquina de calcular estiver fora do seu alcance. Há completa dependência da máquina. A velha geração, da qual faço parte, muitas vezes consegue acabar mentalmente uma conta antes de o vendedor ter efetuado a mesma operação com o computador.

O uso da máquina de calcular ou do computador para fazer operações aritméticas simples é cada vez mais freqüente na escola ou em casa para fazer os deveres de matemática.

Estaremos caminhando para uma atrofia progressiva das funções de cálculo mental? Também neste domínio serão indispensáveis estudos e pesquisas psicopedagógicas para verificar esta hipótese e, caso for confirmada, sugerir às autoridades educacionais medidas adequadas.

\section{Frustrações nas comunicações e relações humanas}

Quase diariamente, muitos de nós estamos nos encontrando com portadores de celulares, e muitos de nós também temos celular.

Para quem usa um celular e o carrega consigo permanentemente, há uma perda de liberdade, pois tem de atender, nunca sabe se o assunto é urgente ou vital.

Por outro lado, se conversarmos com uma pessoa com celular, freqüentes interrupções cortam a comunicação intelectual e afetiva. Neste último caso, um namoro, por exemplo, cria-se uma frustração constante entre os parceiros. Conheço casos de perda de amizade e de ruptura de namoro por esta causa, junto, é claro, com outros fatores. A interrupção durante as refeições acaba causando estresse e úlceras duodenais. Muito frustrantes também são os constantes choques causados por toques de campainhas de celular em plena conferência pública, com as pessoas atendendo em voz baixa, perturbando a audiência. Cada vez mais freqüentes são os avisos dos dirigentes de eventos públicos proibindo o uso de celular durante as palestras ou reuniões.

Algo semelhante acontece com a secretária eletrônica. Você, com toda a alegria, está querendo tomar contato com um amigo querido. Uma voz monótona o atende pedindo deixar uma mensagem. A repetição deste gesto durante anos se torna bastante irritante para muita gente. Mais irritante ainda é ser recebido por uma música suave na hora de precisar de uma informação urgente. Você quer uma informação, e não uma sinfonia de Bethoven. Se você quer uma música, você tem a sua coleção de CD's para isto. Sei que a intenção dos que criaram este sistema de espera era abrandar a frustração da espera. Mas, muitas vezes, é o contrário que se dá.

\section{A NORMOSE TECNOLÓGICA}

\section{Informática, sim! Mas a serviço de que e de quem?}

Tenho bastante consciência de que todas as patologias anteriormente descritas não podem ser atribuídas à informática e à sua tecnologia, mas sim ao modo de uso destas pelos seres humanos. Elas são normóticas na medida em que os comportamentos que as geram são considerados como normais pela maioria da população, embora sejam elas destrutivas da saúde física e ou mental e, às vezes, mortíferas. É aí que reside o maior problema.

Além desta cegueira provocada pelo consenso de normalidade, fica evidente que, conforme o caso, podemos citar como fatores patogênicos principais os seguintes: excesso de entusiasmo e expectativa, apego, egocentrismo e falta de respeito ao outro, desconhecimento pelo usuário dos efeitos de certas aplicações da informática.

É bastante evidente também que, até agora, os aspectos patogênicos da normose informática podem ser evitados, através do esclarecimento pelas mídias e da educação. Por isto que, até agora, só podemos considerar a normose como parcial, por haver a possibilidade do uso sadio e "normal" da informática. 
FIGURA 1

\section{Roda da Destruição}

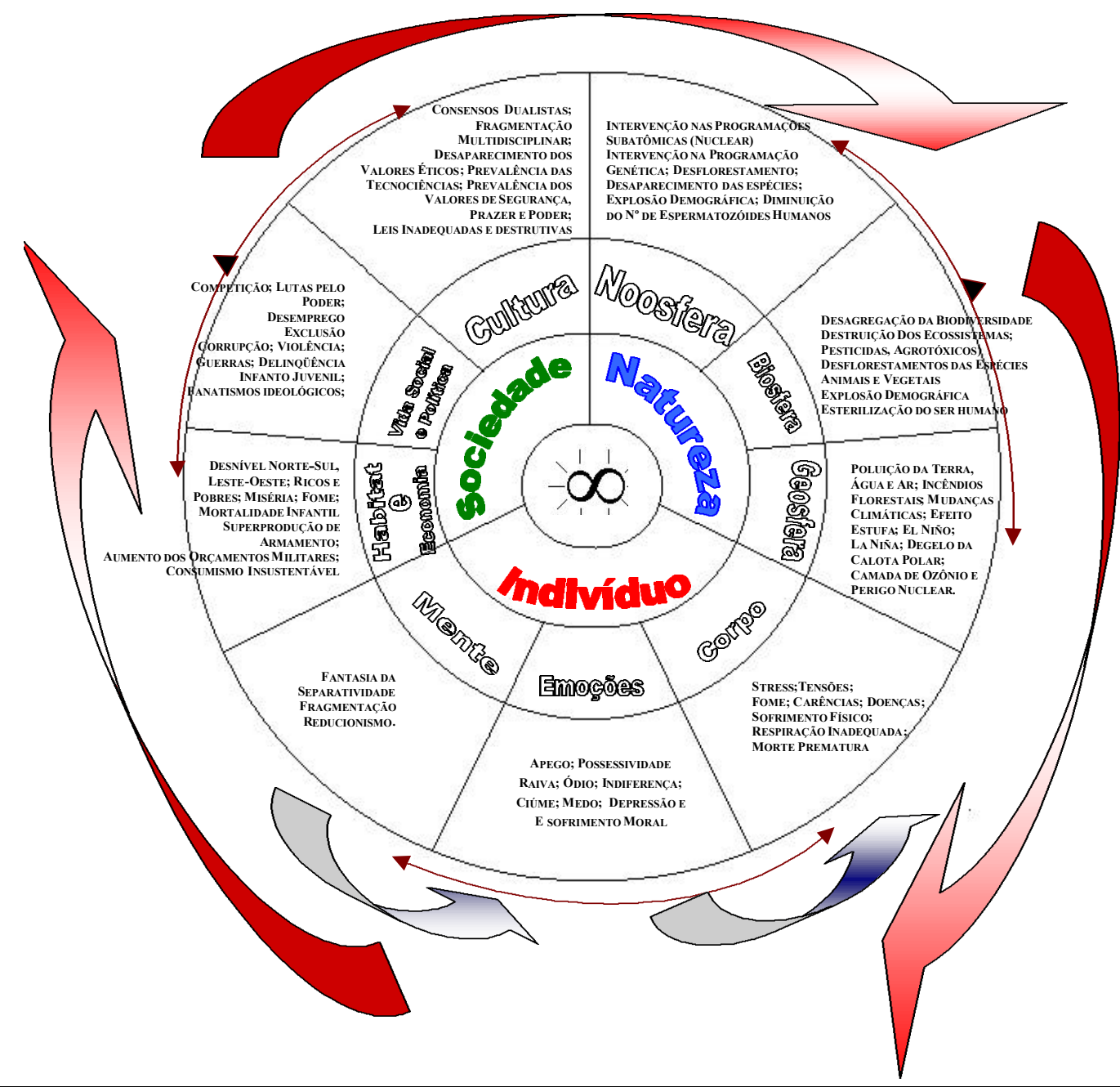

Esta conclusão, no entanto, deve ser considerada como provisória, pois há uma questão muito importante que só agora podemos abordar, por causa da sua abrangência.

Para chegarmos ao cerne desta nova problemática e para que o leitor entenda do que estamos falando, precisamos dar explicações preliminares.

\section{O processo de destruição da vida no planeta}

O leitor vai precisar de um pouco de paciência, pois vai parecer que estamos nos afastando do assunto. $\mathrm{Na}$ realidade, vamos mostrar como a informática está estreitamente envolvida por uma normose muito maior, isto é, a que atrai as tecnologias para atividades destrutivas incluindo nisto a eliminação progressiva da vida no planeta. Em várias publicações anteriores, temos mostrado como o ser humano está chegando a isto, isto é, qual a gênese do auto-suicídio progressivo da humanidade ${ }^{14,15}$.
Esta descrição integra inclusive a Teoria Fundamental da Universidade da Paz de Brasília ${ }^{14}$. Quem se interessar pelos pormenores encontrará as fontes indicadas na Bibliografia do presente trabalho. Vamos nos limitar a descrever o que nos parece essencial para que o leitor possa acompanhar o nosso raciocínio.

O processo destrutivo é um círculo vicioso que constitui o nosso modelo teórico que chamamos de "Roda da Destruição". Ele é constituído de três partes interrelacionadas, a saber: O Indivíduo, a Sociedade e a Natureza. O processo destrutivo começa no indivíduo que cria desarmonia na Sociedade; esta porfeed back reforça a desarmonia individual e destrói a vida do Planeta. Esta destruição, por sua vez, constitui uma ameaça para todos nós como indivíduos. E assim está fechado o grande círculo vicioso que nos afeta (figura 1). 
Ela começa no plano individual por um círculo vicioso de compulsão repetitiva que tem como pano de fundo uma fantasia, a fantasia da separatividade. Trata-se de uma miragem, uma ilusão que nos faz perceber a nós mesmos como separados do mundo exterior; daí decorre uma dualidade sujeito objeto que é responsável pelo fato de nos apegarmos a tudo que nos dá prazer e rejeitarmos tudo que nos causa dor. $\mathrm{O}$ apego cria o medo, o orgulho e o ciúme. Este conjunto emocional nos leva ao estresse, à doença, ao sofrimento, o qual reforça ainda esta fantasia dualista. É o que chamamos de Neurose do Paraíso Perdido $^{21}$.

No plano da sociedade, uma cultura baseada em um consenso dualista criou a maior crise de fragmentação da nossa história com mais de duas mil disciplinas e umas 800 interfaces, o que torna as nossas universidades verdadeiras torres de Babel, afetando a vida social sob forma de competição desenfreada que no plano econômico nos traz o consumismo descontrolado.

O aspecto mais importante para o nosso assunto é que esta fragmentação, por causa da necessidade de objetividade na ciência, fez esta se separar da ética, a qual ficou relegada para a filosofia e a religião. Resulta disto uma neutralidade no domínio da tecnologia cujas conseqüências nós vamos examinar agora.

\section{A "neutralidade" científica na tecnologia}

O mito da objetividade na ciência acarretou a necessidade de esta se tornar neutra em relação a qualquer ideologia política, religiosa ou espiritual. Com isto, a ciência se afastou dos valores éticos, mesmo se certos aspectos axiológicos ainda permanecem nos juramentos das formaturas. Como na atualidade a maioria das disciplinas reclama de objetividade científica, a neutralidade impregnou todas as aplicações da ciência, e isto se estendeu a todas as tecnologias.

E este é o aspecto mais grave da nossa civilização: considera-se normal que as tecnologias e os seus profissionais se coloquem a serviço de qualquer valor, seja ele construtivo, destrutivo ou neutro em relação à vida. Quando redigi os meus dois livros, um sobre uma nova ética ${ }^{16} \mathrm{e}$ o outro sobre as tecnologias e organizações para o terceiro milênio ${ }^{20}$, dei-me conta de três realidades estarrecedoras:

- a primeira é que muitas tecnologias e tecnocratas estão a serviço de valores destrutivos, tais como ferir, torturar, destruir a vida sob todas as formas e matar;
- a segunda realidade é que quem carrega e utiliza as tecnologias são justamente as organizações e as empresas;

- a terceira realidade é que isto é considerado como normal pelos governos, pelos empresários e executivos, assim como pela maioria esmagadora das populações deste planeta.

E agora chegamos ao cerne da questão da normose informacional. Ela é apenas um caso particular desta normose mais genérica que acabamos de descrever. Mas é mais eficaz nos seus aspetos patogênicos e letais. Em outras palavras, ela contribui diretamente para ferir e matar com muito mais precisão!

\section{A Informação sem ética}

Suponho que fica agora claro para o leitor que a informática também está a serviço de qualquer valor, incluindo os destrutivos. Muito mais, graças à sua utilização, as diferentes tecnologias de destruição se tornam mais eficazes ainda com a ajuda do computador, mais particularmente se levarmos em consideração os diferentes tipos de robôs atualmente em uso sob forma de foguetes, bombas de diferentes tipos e assim por diante.

Não há dúvida de que se trata de uma normose, pois todo mundo acha natural que a tecnologia em geral e a informática em particular sejam aplicadas com fins militares, pois forças armadas são consideradas como normais. Isto levanta inclusive a questão da normose militar sobre a qual ainda não concentramos a nossa lente.

Uma questão mais grave ainda é a das aplicações da informática às intervenções tecnológicas nos programas nuclear e genético. Muitos estão se perguntando se é lícito e saudável usar a energia atômica para produzir eletricidade, já que se sabe que serão precisos dezenas de milhares de anos para apagar o núcleo de um reator atômico em caso de acidente ou de deterioração da matéria pela corrosão dos anos. Chernobyl, com as suas dificuldades neste sentido, está aí para nos alertar do risco de nós sacrificarmos a existência dos nossos filhos e netos. $\mathrm{O}$ Átomo para Paz tem um slogan que criou um consenso segundo o qual as indústrias atômicas a serviço da produção de eletricidade podem ser consideradas como normais. Criou-se mais uma normose, pois Chernobyl constitui um franco desmentido a esta normalidade, ou melhor, a esta inocuidade. 
No que se refere às aplicações da informática nos domínios da genética, não temos ainda informações suficientes sobre a periculosidade das intervenções das tecnologias informáticas neste campo. Por exemplo, o enorme sucesso do programa Genoma, com as suas perspectivas de cura ou de prevenção de doenças hereditárias tradicionalmente incuráveis, encobre em parte as perspectivas dos eventuais perigos da clonagem e das sementes geneticamente modificadas. Todo mundo se assusta também com a idéia de criar corpos humanos clonados para reserva de órgãos de transplante.

A gritaria é grande, e as controversas alimentadas por interesses nem sempre confessáveis também se desenvolvem rapidamente. Estamos todos alarmados.

Está agora na hora de examinarmos o que se pode fazer em termos do que batizamos de Normoterapia ${ }^{6}$.

\section{A NORMOTERAPIA DA NORMOSE INFORMACIONAL}

Chamamos de Normoterapia o conjunto de providências e métodos de transformação no plano individual, social e ambiental que visam a restabelecer a normalidade saudável e desejável pela dissolução do consenso normótico, isto é, patogênico e/ou letal. Vamos começar pela normoterapia individual.

Podemos distinguir aqui dois planos de ação: o educacional e o terapêutico propriamente dito.

O educacional, de natureza preventiva, consistirá em incluir, nos programas escolares, noções sobre os benefícios e perigos da informática e das tecnologias em geral, alertando sobre os diferentes aspectos assinalados anteriormente, da informatose, da cibernose e da normose tecnológica. Para adultos, campanhas de ética no uso das tecnologias se revelam bem eficientes. O exemplo do caso da normose do cigarro é bastante eloqüente.

No que se refere à terapia individual da informatose e da cibernose, o que me ocorre para cada caso é o seguinte.

O caso da dissonância cognitiva pode ser tratado simplesmente pela conscientização das limitações pessoais. Evitar o abuso do computador se aplica também no caso da eventual simbiose neurocibernética. A neurose virtual já nos parece ter uma terapia própria. Na publicação da Unesco sobre a violência nas mídias ${ }^{11}$, um dos autores recomenda uma prática bastante interessante e profilática; consiste em reunir as crianças depois do filme e comentar os diferentes trechos de modo ético e crítico. Outro artigo observa a tendência natural das crianças em brincar e catartizar as cenas de violência. O psicodrama teria papel importante em um trabalho terapêutico. A reequilibração dos hemisférios cerebrais já tem as suas próprias terapias que se encontram sob a forma de despertar da criatividade por meio do uso de diferentes artes.

Não temos ainda informações suficientes sobre a hipótese da atrofia das funções numéricas. De qualquer forma, já convém, a título preventivo, manter e talvez até reforçar o calculo mental nas escolas. Quanto ao uso de celular e secretária eletrônica, eis uma excelente oportunidade para os seus usuários desenvolver a empatia, colocando-se no lugar dos outros e usando estas aparelhagens com a delicadeza e o respeito que todo ser humano merece.

Acabamos de fazer algumas sugestões em um terreno ainda quase virgem. Por isto fazemos a ressalva de que cada uma destas sugestões merece estudos pormenorizados por profissionais competentes em cada assunto. $\mathrm{O}$ mesmo podemos afirmar no que se refere à normoterapia nos planos social e ambiental. É disto que vamos tratar a título de término deste trabalho.

\section{Normoterapia social e ambiental}

São, pelo menos em função do presente levantamento, dois aspetos essenciais que precisam de uma ação global no plano social e visando também à preservação ambiental, isto é, da vida neste planeta. Vamos examinar cada um deles sob o prisma de uma normoterapia.

O primeiro aspecto é o uso da informação para fomentar a violência no espírito de incontáveis seres humanos, mais particularmente jovens, além de ajudar a aperfeiçoar os processos de assaltos.

O segundo é o que ressaltou o fato de que o uso da informação e, mais particularmente, da tecnologia informacional para fins destrutivos inscreve-se dentro de uma normose mais geral, que chamamos de normose tecnológica.

De fato, o primeiro aspecto é apenas um caso particular do segundo, pois a violência é por natureza o ato destrutivo por excelência. Sendo assim, encontramo-nos com um só problema: o da normoterapia da normose tecnológica em geral, que inclui a normose informacional como um caso particular da normose tecnológica. 
Parece-me que, em primeiro lugar, temos de enunciar um princípio geral de ética, cuja função será a de nortear um conjunto de ações normoterápicas interdisciplinares. Eis o princípio que propomos:

Deve ser banido o uso de toda e qualquer tecnologia a serviço da destruição ou deterioração da vida sob todas as suas formas vegetal, animal e humana - e/ou que constitui uma transgressão à Declaração Universal dos Direitos Humanos.

No entanto, deve ser encorajado o uso de tecnologias que propiciam alimentos sadios em quantidade suficiente, e não mais para alimentar a população humana do mundo, de forma viável, isto é, sem deteriorar o meio ambiente.

A aplicação deste princípio implica uma estratégia das Nações Unidas e dos governos de cada país no sentido de incentivar medidas legislativas que regulam a aplicação deste princípio ético. Paralelamente, universidades e ou instituições governamentais de pesquisas deverão definir quais as tecnologias a serem banidas.

Estudos e pesquisas precisam ser efetuados para que possam esclarecer em quais campos tecnológicos destrutivos, construtivos ou neutros a tecnologia informática e/ou geral está atuando. E para isto precisamos de uma classificação destas tecnologias e dos seus produtos nestas três categorias. Não é de hoje que sentimos esta necessidade. Já quando redigimos o nosso livro sobre a nova ética, fizemos uma proposta de uma classificação desta ordem, para servir de guia para o que é conhecido hoje em economia pelo conceito de "investimento ético", do qual vamos falar a seguir.

Tal pesquisa deverá ser de natureza inter e eventualmente transdisciplinar no sentido que definimos em outro livro ${ }^{17}$, e no do físico Basarab Nicolescu ${ }^{18}$, e da Declaração de Veneza da Unesco ${ }^{19}$.

Eis como imaginamos a estrutura desta listagem, com alguns exemplos colhidos dentro da limitação dos nossos conhecimentos, mas que já recomendamos em outra publicação $^{16}$.

Tecnologias construtivas (alguns exemplos):

- fabricação de material ótico;

- fabricação de material escolar;tecnologias de agricultura natural; planejamento e montagem de Ecovillage;

- recuperação de bacias hidrográficas;tecnologias de educação para a paz;desenvolvimento de plantio de algodão;
- construção de aparelhos de diagnostico médico;

- construção de carros movidos à energia solar ou outro meio não poluente;

- fabricação de microscópios eletrônicos.

Tecnologias destrutivas (alguns exemplos):

- fabricação de armas de guerra;

- fabricação de bombas atômicas, químicas e biológicas;

- fabricação de carros movidos à gasolina ou outros poluentes;

- produção de agrotóxicos;

- fabricação de cigarros.

Tecnologias neutras (alguns exemplos):

- fabricação de perfumes;

- fabricação de esmalte para unhas;

- aparelhos de barbear;

- fabricação de móveis de estilo.

Listagens ou catálogo desta natureza irão incluir um número imprevisível de atividades; os critérios de classificação precisarão ser sistematizados por equipes interdisiciplinares isentas de envolvimentos com interesses econômicos outros; precisarão ser preparados por institutos idôneos de pesquisas e servirão não somente para cadastros de companhias e bancos empenhados em investimentos éticos, mas ainda para nova legislação sobre o assunto, assim como autodisciplina das empresas usando tecnologias destrutivas. Sem trabalhos desta natureza, as recomendações da ECO 92 continuarão como letra morta, e o processo de destruição da vida irá se acentuando.

Como são os organismos públicos e sobretudo as empresas particulares que usam e aplicam as tecnologias, é indispensável uma ação concentrada sobre estas. Várias direções nos ocorreram, a saber:

- reforçar ainda mais as pressões legais de proteção à saúde e à vida ambiental;

- regulamentar as aplicações financeiras dos bancos públicos e particulares dentro do conceito de investimento ético, de tal modo que só se outorguem empréstimos a firmas que usam tecnologias construtivas ou neutras e produzem serviços ou mercadorias no mesmo sentido;

- desenvolver campanhas e sistemas de reciclagem de presidentes, executivos e gerentes no sentido de desenvolvimento de culturas organizacionais holísticas, tal como as definimos em livro sobre o assunto $^{20}$. 


\section{CONCLUSÃO}

E com isto terminamos este artigo em que mostramos três aspectos do caráter destrutivo da informação, aspectos considerados como normais por consenso e por isto mesmo constituindo a Normose Informacional, a saber: a informatose, a cibernose e o reforço da normose tecnológica pela informática.

Para cada um destes aspectos, uma vez sumariamente descritos e analisados, indicamos como se poderia aplicar uma normoterapia, visando a erradicar definitivamente esta ameaça a nossa sobrevivência neste planeta.

Emito o voto para que este artigo, em vez de ser simplesmente elogiado, criticado e arquivado em seguida, sirva de incentivo e fonte de inspiração para o início de programas e projetos de pesquisa e de ação que se revelam urgentes e inadiáveis, por se tratar da nossa própria proteção como indivíduos e sobrevivência da nossa espécie. Se isto acontecer, serei feliz por ter atingido o meu propósito.

\section{REFERÊNCIAS BIBLIOGRÁFICAS}

1. MOORE, NICK. A sociedade de informação. In: A INFORMÇÃO: tendências para o novo milênio. Brasília : IBICT, 1999. p. 94 108.

2. LELOUP, Jean Yves, WEIL, PIERRE. Les deux extremes de la normose contemporaine: le phantasme de la separativité et le phantasme fusionnel. Paris : 3 eme Millénaire, 1995.

3. CREMA, Roberto. Análise transacional centrada na pessoa e mais além...São Paulo : Ed. Agora, 1985. p. 161.

4. WEIL, Pierre. Les anomalies de la normalité. Paris : 3eme Millénaire, 1994. (n. 30-31).

5. WEIL, Pierre. Normose: a patologia da normalidade. São Paulo Thot, 1997. (n. 64).

6. WEIL, Pierre. Mudança de sentido: o sentido da mudança. Rio de Janeiro : Rosa dos Tempos, 2.000. p. 121.

7. CRONIN, Blaise, MCKIM, Geoffrey. Internet. Brasília: IBICT, 1999. p. 63.

8. WEIL, Pierre. Dinâmica de grupo e desenvolvimento em relações humanas. Belo Horizonte : Itatiaia, 1967. p. 12

9. DE CHARDIN, Theilhard. La place de l'homme dans la nature. Paris : Le Seuil, 1958.

10. SCHREIBER, Servan Jacques. O desafio mundial. Rio de Janeiro: Nova Fronteira. 1980. p. 165

11. UNESCO (Paris) Léducation aux médias. Paris, 1984.

12. VALENTE, José Armando (Org.). Computadores e conhecimento: repensando a educação. [Campinas] : Gráfica Central da UNICAMP, 1993.

13. WEIL, Pierre. Mudança de sentido: o sentido da mudança. Rio de Janeiro : Rosa dos Tempos, 2.000. p. 243.

14. WEIL, Pierre. Mudança de sentido: o sentido da mudança. Rio de Janeiro : Rosa dos Tempos, 2.000. p. 165.

15. WEIL, Pierre. Sementes para uma nova era. Petrópolis : Vozes, 1997.

16. WEIL, Pierre. A nova ética. Rio de Janeiro : Rosa dos Tempos, 1998. p. 87-89.

17. WEIL, Pierre, D'AMBROSIO, Ubiratan, CREMA, Roberto. Rumo á uma nova transdisciplinaridade. São Paulo : Summus, 1996.

18. BASARAB, Nicolescu. Manifesto da transdisciplinaridade. [s. ed., 2000?].

19. Unesco (Paris). A declaração de Veneza. Paris, 1986.

20. WEIL, Pierre. Tecnologias e organizações para o século XXI: a nova cultura organizacional holística. Rio de Janeiro : Rosa dos Tempos, 1997.

21. WEIL, Pierre. A neurose do paraíso perdido. Rio de Janeiro : CEPA - Espaço Tempo, 1991.

22. BONECO morre na cadeira elétrica. Diário Catarinense, Florianópolis, 10 set. 2.000. p. 42.

23. BRASIL. Ministério da Educação. Secretária Geral. Programa Nacional de Informática Educativa. [Brasília], 1989. 